\title{
CORRELATION OF POPULATION AND ENVIRONMENTAL BEHAVIOR WITH RAT DENSITY RATE IN PLAGUE DISEASE-FOCUS, THREATENED AND SAFE AREAS IN TUTUR DISTRICT, PASURUAN REGENCY, 2016
}

\author{
Evi Noerista Lestari ${ }^{1}$, Susilowati Andajani ${ }^{2}$, Usman Hadi $^{3}$ \\ ${ }^{1}$ Tropical Medicine Master Program, ${ }^{2}$ Department of Public Health, ${ }^{3}$ Department of Internal Medicine, Faculty of \\ Medicine, Universitas Airlangga, Surabaya, Indonesia
}

\section{ABSTRACT}

Plague disease remains a public health problem in the world. According to the International Health Regulations (IHR), an outbreak is an infectious disease that has the potential to cause an outbreak. The purpose of this study was to analyze a significant relationship between human behavior and the environment with the density of the number of rats in the focus, threatened and outbreak-safe areas in Tutur Regency, Pasuruan Regency, in 2016. This was an observational analytic study with cross correlation sectional where the research variables are population behavior, environment, and the number of rat densities observed once at a time. The results showed that there was no significant relationship between the behavior (knowledge, attitude, and practice) of the population with the density of rats in the focus area of the Surorowo hamlet outbreak, in the endangered outbreaks of the Ngaro hamlet, and in the outbreak-safe area of the North Ngandong hamlet in Tutur District. Whereas, there is a significant relationship between environmental conditions and the amount of rat density in the focus area of the outbreak of the Surorowo hamlet ( $p: 0.047$ or $p<0.05$ ), the threatened area of the Ngaro hamlet ( $p: 0.036$ or $p<0.05)$, and at outbreak-safe areas in Andong Utara hamlet ( $p$ : 0.047 or $p<0.05)$. Conclusion: Environmental conditions are associated with the amount of rat density either in the outbreak, in focus, threatened, or in safe areas. That it is necessary to control environmental risk factors to reduce the amount of rat density.

Keywords: Plague; the density of rats; environmental conditions

\section{ABSTRAK}

Penyakit pes tetap menjadi masalah kesehatan masyarakat di dunia. Menurut Peraturan Kesehatan Internasional (IHR), wabah adalah penyakit menular yang berpotensi menyebabkan wabah. Tujuan dari penelitian ini adalah untuk menganalisis hubungan yang signifikan antara perilaku manusia dan lingkungan dengan kepadatan jumlah tikus dalam area fokus, terancam, dan wabahaman di Kabupaten Tutur, Kabupaten Pasuruan, pada 2016. Metode: Penelitian ini merupakan penelitian observasional analitik dengan korelasi cross sectional dimana variabel penelitiannya adalah perilaku populasi, lingkungan, dan jumlah kepadatan tikus yang diamati satu kali sekaligus. Hasil penelitian menunjukkan bahwa tidak ada hubungan yang signifikan antara perilaku (pengetahuan, sikap, dan praktik) populasi dengan kepadatan jumlah tikus di daerah fokus wabah dusun Surorowo, di wabah terancam punah dusun Ngaro, serta di daerah wabah-aman dusun Ngandong Utara di Kabupaten Tutur. Sementara itu ada hubungan yang signifikan antara kondisi lingkungan dengan jumlah kepadatan tikus di area fokus wabah 'dusun Surorowo (p: 0,047 atau $p<0,05$ ), area terancam dusun Ngaro (p: 0,036 atau p <0,05), dan pada daerah wabah-aman di dusun Andong Utara (p: 0,047 atau $p$ <0,05). Kesimpulan: Kondisi lingkungan dikaitkan dengan jumlah kepadatan tikus baik di wabah, fokus, terancam, atau daerah aman. Bahwa perlu untuk mengendalikan faktor-faktor risiko lingkungan untuk mengurangi jumlah kepadatan tikus.

Kata kunci: Wabah; kepadatan tikus; kondisi lingkungan

Correspondence: Evi Noerista Lestari, Tropical Medicine Master Program, Faculty of Medicine, Universitas Airlangga, Surabaya, Indonesia. Phone: (+62)8123259248. E-mail: noeristaevi@yahoo.com

pISSN:2355-8393 • eISSN: 2599-056x • doi: http://dx.doi.org/10.20473/fmi.v55i4.17314

- Fol Med Indones. 2019;55:260-267 • Received 9 Feb $2017 \bullet$ Accepted 10 Aug 2017

- Open access under CC-BY-NC-SA license • Available at https://e-journal.unair.ac.id/FMI/

\section{INTRODUCTION}

Plague disease is still a public health problem in the world. The International Health Regulation (IHR) states that plague disease is an infectious disease that has the potential to cause an outbreak. Under Law number 1 of
1962, plague disease is included in quarantine, so that if there is an epidemic of plague disease, the area will be isolated. This has a big impact on the economy, social politics and national security. The Republic of Indonesia's Minister of Health Decree number 1501 of 2010 also mentions plague disease as a disease that can 
cause an outbreak. plague disease is also a disease that has the potential to cause urgent public health problems and can cause international unrest or better known as the Public Health Emergency of International Concern (PHEIC).

According to the World Health Organization (WHO) in 2016, throughout 2014 there was an outbreak of plague disease in Madagascar with 482 patients with 112 deaths. In 2015 there were 275 patients with 63 deaths. Madagascar has continued to experience bubonic plague almost every year since 1980. This makes Madagascar the country most severely affected by plague disease worldwide (WHO, 2016). In 2015 in the United States (United States) obtained 11 patients with plague disease with 3 deaths (CDC, 2015). In Asia in 2009 there were 13 patients in China with 11 deaths, while in 2015 there were 3 sufferers in Mongolia with 2 deaths (WHO 2016).

In Indonesia, the focus area of plague disease is in three provinces, namely Central Java Province in Boyolali District, Selo and Cepogo Districts, Yogyakarta Special Region Province in Cangkringan District, and East Java Province in Pasuruan Regency, namely in Tutur, Tosari, Puspo and Pasrepan Districts. Of the three provinces, there are still cases of plague disease in humans found only in East Java Province. The latest report in 2007 was 82 cases of plague disease. In Java Province the plague disease was reported to occur in November 1986 in the hamlet of Surorowo, Tutur District, Pasuruan Regency. Investigations in the field found 24 cases with 20 deaths (CFFR - 83\%) and in February April 1987 in the same place found 224 cases with 1 death. In 1997 (10 years later) it was reported to be found in Surorowo hamlet in 6 cases with no mortality, and in 2007 again there were reported fever sufferers with no known cause as many as 82 cases with 1 death rate. In February 2009, in Surorowo Hamlet, Kayukebek Village, I was found to suspect plague disease, but the results of serological and bacteriological examination were negative. Based on data from plague disease surveillance observations conducted by BBTKLPP Surabaya in June 2015, no plague disease suspect was found but the plague disease antibody titer was still found in rats between 1: 4 to 1:16. Of 1660 serums examined (1659 rat serums and 1 suspect human serum), 56 serums containing plague disease antibodies with a titer of $1: 16(0.66 \%), 1: 8$ $(1.45 \%)$ and $1: 4(1.27 \%)$.

Data from BBTKLPP Surabaya Zoonosis Laboratory in Nongkojajar said there were still antibody titers found in the last three years both in humans and rats as well as GPA $>1$ in both focus and threatened areas in Tutur District. This situation has the potential to cause a plague disease outbreak again if the behavior of the population and the environment in the area is supportive. Surorowo Hamlet is a hamlet in the village of Kayu Kebek, Tutur District, Pasuruan Regency. Most residents work as farmers in apples and vegetables. Means of worship in the form of castles and worship centers for Hindus and mosques for Muslims. In the village there is a place (in the form of a small forest) that is sacred and the locals call it "petren", where no one is allowed to take everything in the forest. Surorowo sub-village is included in a special focus area for observing bubonic plague so routine rat traps are installed every 2 weeks. In each activity 1000 traps were installed, two traps in each house, if there were rats trapped the community deposited at the collection post at the house of the rodent surveillance officer. Other community participation in this village is the installation of insecticidal pardons to control rat fleas. The environment is one factor that is very important for the life of living things, such as humans, animals, plants and microorganisms. The environment must be managed properly so that animals that transmit diseases in this case rats cannot breed around them. Rats are known as cosmopolitan animals that can occupy all habitats in the environment such as houses, rice fields, forests, waterways, trees, and can transmit bubonic plague to humans through fleas bite as vectors and bubonic plague. (Ministry of Health of RI 2012).

\section{MATERIALS AND METHODS}

The design of this study was a cross sectional comparative study observational analytic study. In this study the research variables of population behavior, environment and rat density were observed only once at the same time. The population of this study is adult population and the environment in the focus area (Surorowo Hamlet), threatened areas (Ngaro Hamlet) and safe areas (Andong Utara Hamlet) in Tutur Subdistrict, Pasuruan Regency in 2016. The research sample is adult population and environment in Surorowo Hamlet, Ngaro and Andong Utara, Tutur Subdistrict, Pasuruan Regency, in 2016 were taken as sample units and were willing to be respondents of the study, with a sample size of each hamlet determined by 50 people. The sampling technique in this study uses simple random sampling.

This study used independent variables consisting of population behavior about plague disease consists of knowledge of the population, attitudes of the population, actions of the population and environment includes the physical environment, biological environment, chemical environment. Whereas, the dependent variable in this study was the rat density. 
The study was conducted in Tutur Subdistrict, Pasuruan, with a research period from September-December 2016. Data collection was carried out by interviewing selected residents with structured questionnaires which included data on knowledge, attitudes and actions about plague disease. Residential housing environmental data is collected by observing the house and the environment around the respondent's house. Rat data were obtained by trapping with metal live rat catchers to catch rats inside and outside the resident's home for 5 consecutive days as many as 200 traps every day so that the total traps were installed for 5 days 1000 pieces. To obtain blood in large quantities and in a short time used intracranial blood collection methods followed by taking rat tissue for bacteriological examination. After blood and organ harvesting, rat identification was performed. To determine the type of rat used external morphological signs which include a quantitative way of measuring and weighing and a qualitative way of observing the color and type of hair. Calculation of rat density using the formula:

$$
\frac{\text { number of rats trapped }}{\text { the number of traps installed }} \times 100 \%
$$

Fleas collected are identified by species, counted and recorded on the label provided. The fleas will be isolated by the Y. plague diseasetis bacteria, then the fleas will be injected into white rats. White rats are monitored for 21 days, if someone dies they will be autopsied to obtain tissue for bacterial isolation. After the monitoring period, the white rats are destroyed in the incinerator. The method of calculating the fleet index is GPA = Number of fleas $\mathrm{X}$. cheopis found divided by the number of trapped rats. IPU = number of fleas other than X. cheopis found divided by the number of trapped rats.

This study used descriptive and bivariate inferential analysis with regression test $(\mathrm{a}=0.05)$. Multivariate analysis using linear regression test was also carried out.

\section{RESULTS}

Bacteriological examination was carried out on fleas of 11 pools. Like bacteriological examination of rat tissue, in crushed fleas and injected in white rats also did not get death.

Based on Table I can be seen that the results of regression tests between environmental conditions and rat density in the hamlet of Surowowo (Fokus), Tutur District, Pasuruan Regency in 2016 showed a p value of 0.049 or $\mathrm{p}<0.05$ which means that there is a significant relationship between environmental conditions with rat density. The correlation coefficient value - 0.116 indicates a weak relationship, while negative indicates the opposite direction that the worse the environmental conditions, the higher the rat density or vice versa if the environmental conditions are good the rat density is low. Regression test results also show the $\mathrm{p}$ value of the behavior of 0.734 or $p>0.05$ which means there is no relationship between the behavior of the population with the rat density in the Surorowo village (focus), Tutur District, Pasuruan Regency in 2016.

Table 1. Results of regression analyzes of environmental conditions and behavior with rat density in Dusun Surorowo (focus), Tutur District, Pasuruan Regency, 2016

\begin{tabular}{ccccl}
\hline No & \multicolumn{1}{c}{ Variables } & $\begin{array}{c}\text { Correlation } \\
\text { coefficient }\end{array}$ & Significance & \multicolumn{1}{c}{ Interpretation } \\
\hline 1 & Environmental condition & -0.116 & 0.049 & $\begin{array}{l}\text { Negative, weak } \\
\text { correlation, } \\
\text { significant } \\
\text { No correlation }\end{array}$ \\
\hline
\end{tabular}

Table 2. Results of regression analyzes of environmental conditions and behavior with rat density in Ngaro Hamlet (threatened), Tutur District, Pasuruan Regency in 2016

\begin{tabular}{ccccl}
\hline No & \multicolumn{1}{c}{ Variables } & $\begin{array}{l}\text { Correlation } \\
\text { coefficient }\end{array}$ & Significance & \multicolumn{1}{c}{ Interpretation } \\
\hline 1 & Environmental condition & -0.312 & 0.045 & $\begin{array}{l}\text { Negative, weak } \\
\text { correlation, } \\
\text { significant } \\
\end{array}$ \\
& & & & No correlation \\
\hline
\end{tabular}


Table 3. Results of correlation analysis of environmental and behavioral regression conditions with rat density in Andong Utara (safe) Hamlet, Tutur sub-district, Pasuruan Regency in 2016

\begin{tabular}{ccccl}
\hline No & \multicolumn{1}{c}{ Variables } & $\begin{array}{c}\text { Correlation } \\
\text { coefficient }\end{array}$ & Significance & \multicolumn{1}{c}{ Interpretation } \\
\hline 1 & Environmental condition & -0.185 & 0.037 & $\begin{array}{l}\text { Negative, weak } \\
\text { correlation, } \\
\text { significant }\end{array}$ \\
& & & 0.677 & No correlation \\
\hline
\end{tabular}

Table 4. Results of Anova-one way Environment Analysis in Surorowo, Ngaro, and Andong Utara Hamlet, Tutur District, Pasuruan Regency, 2016

\begin{tabular}{|c|c|c|c|c|c|c|c|c|c|c|}
\hline \multirow{3}{*}{ Hamlet name } & \multicolumn{8}{|c|}{ Environment } & \multirow{3}{*}{$\mathrm{p}$} & \multirow{3}{*}{ Interpretation } \\
\hline & \multicolumn{2}{|c|}{$33-43$} & \multicolumn{2}{|c|}{$44-55$} & \multicolumn{2}{|c|}{$56-66$} & \multicolumn{2}{|c|}{ Total } & & \\
\hline & $\mathrm{N}$ & $\%$ & $\mathrm{~N}$ & $\%$ & $\mathrm{~N}$ & $\%$ & $\mathrm{~N}$ & $\%$ & & \\
\hline $\begin{array}{l}\text { Surorowo } \\
\text { (focus) }\end{array}$ & 0 & 0 & 15 & 30 & 35 & 70 & 50 & 100 & 0.000 & $\begin{array}{l}\text { Different, } \\
\text { significant }\end{array}$ \\
\hline $\begin{array}{l}\text { Ngaro } \\
\text { (threatened) }\end{array}$ & 0 & 0 & 30 & 60 & 20 & 40 & 50 & 100 & & \\
\hline $\begin{array}{l}\text { Andong } \\
\text { Utara (safe) }\end{array}$ & 5 & 10 & 33 & 66 & 12 & 24 & 50 & 100 & & \\
\hline
\end{tabular}

Table 5. Results of the Kruskal-Wallis Analysis of Knowledge Differences in Surorowo Hamlet, Ngaro and Andong Utara, Tutur District, Pasuruan Regency, 2016

\begin{tabular}{|c|c|c|c|c|c|c|c|c|c|c|}
\hline \multirow{3}{*}{$\begin{array}{c}\text { Hamlet } \\
\text { name }\end{array}$} & \multicolumn{8}{|c|}{ Knowledge } & \multirow{3}{*}{$\mathrm{p}$} & \multirow{3}{*}{ Interpretation } \\
\hline & \multicolumn{2}{|c|}{$0-65$} & \multicolumn{2}{|c|}{$66-95$} & \multicolumn{2}{|c|}{$96-120$} & \multicolumn{2}{|c|}{ Total } & & \\
\hline & $\mathrm{N}$ & $\%$ & $\mathrm{~N}$ & $\%$ & $\mathrm{~N}$ & $\%$ & $\mathrm{~N}$ & $\%$ & & \\
\hline $\begin{array}{l}\text { Surorowo } \\
\text { (focus) }\end{array}$ & 1 & 2 & 41 & 82 & 8 & 16 & 50 & 100 & 0.000 & $\begin{array}{l}\text { Different, } \\
\text { significant }\end{array}$ \\
\hline $\begin{array}{l}\text { Ngaro } \\
\text { (threatened) }\end{array}$ & 10 & 20 & 27 & 54 & 13 & 26 & 50 & 100 & & \\
\hline $\begin{array}{l}\text { Andong } \\
\text { Utara (safe) }\end{array}$ & 46 & 92 & 3 & 6 & 1 & 2 & 50 & 100 & & \\
\hline
\end{tabular}

Based on Table 2 it can be seen that the results of the regression test between environmental conditions and rat density in Ngaro (threatened) Hamlet, Tutur District, Pasuruan Regency in 2016 showed a p value of 0.045 or $\mathrm{p}<0.05$ which means that there is a significant relationship between environmental conditions and rat density . Correlation coefficient value - 0.312 indicates a weak relationship while negative indicates that the worse the environmental conditions, the higher the density of rats or vice versa when the environmental conditions are good the rat density is low.

Based on Table 3, it can be seen that there is weak and negative significant correlation between environmental condition and rat density in Andong Utara (Safe) Hamlet, Tutur District, Pasunan Regency 2016. Regression test results between environmental conditions and rat density in Andong Utara hamlet show the value of $p$ is 0.037 or $p<0.05$ which means that there is a significant relationship between environmental conditions and rat density. The negative correlation coefficient value indicates that the worse the environmental conditions, the higher the rat density or vice versa if the environmental conditions are good the rat density is low. Regression test results between population behavior and rat density in Andong Utara sub-village showed $p$ value was 0.677 or $p>0.05$, which means there was no relationship between knowledge of population and rat density. The correlation coefficient value - 0.185 indicates a weak correlation while the negative symbol indicates that the worse the behavior of the population, the higher the density of rats or vice versa if the behavior of the population is good, the low density of rats.

Based on Table 4, it can be seen that the Anova-one way test results show that the $p$ value is $0,000(p<0.05)$ which means that there are significant differences between the environmental conditions in Surorowo, Ngaro and Andong Utara hamlets, Tutur District, Pasuruan Regency in 2016. 
Based on Table 5, it can be seen that the value of $p$ $<0.05$ means that there is a significant difference between the knowledge of the population in the villages of Surorowo, Ngaro and Andong Utara, Tutur District. Pasuruan Regency in 2016. Based on Table 6 it can be seen that there are significant differences between the attitudes of the population in the villages of Surorowo, Ngaro and Andong Utara, Tutur District, Pasuruan Regency in 2016. Whereas, based on Table 7 it can be seen that there are significant differences between the actions of the population in the villages of Surorowo, Ngaro and Andong Utara, Tutur District, Pasuruan Regency in 2016.

Based on Table 8 it can be seen that there are significant differences, between the population density of rats in the hamlets of Surorowo, Ngaro and Andong Utara, Tutur District, Pasuruan Regency, in 2016. Prediction of rat density numbers using independent variables as predictors can be seen in Table 9.

Table 6. Results of Kruskal-Wallis Analysis of Differences in Attitudes in Surorowo, Ngaro, and Andong Utara Villages, Tutur District, Pasuruan Regency, 2016

\begin{tabular}{lcccccccccc}
\hline \multirow{2}{*}{$\begin{array}{c}\text { Hamlet } \\
\text { name }\end{array}$} & \multicolumn{1}{c}{$0-55$} & $56-79$ & $80-100$ & \multicolumn{2}{c}{ Total } & \multirow{2}{*}{$\mathrm{p}$} & Interpretation \\
\cline { 2 - 7 } & $\mathrm{N}$ & $\%$ & $\mathrm{~N}$ & $\%$ & $\mathrm{~N}$ & $\%$ & $\mathrm{~N}$ & $\%$ & & \\
\hline $\begin{array}{l}\text { Surorowo } \\
\text { (focus) }\end{array}$ & 2 & 4 & 12 & 24 & 36 & 72 & 50 & 100 & 0.000 & $\begin{array}{c}\text { Different, } \\
\text { significant }\end{array}$ \\
$\begin{array}{l}\text { Ngaro } \\
\text { (threatened) }\end{array}$ & 10 & 20 & 19 & 38 & 21 & 42 & 50 & 100 & & \\
$\begin{array}{l}\text { Andong } \\
\text { Utara (safe) }\end{array}$ & 20 & 40 & 22 & 44 & 8 & 16 & 50 & 100 & & \\
\hline
\end{tabular}

Table 7. Results of Kruskal-Wallis Analysis of Difference in behavior in Surorowo, Ngaro, and Andong Utara Hamlet, Tutur District, Pasuruan Regency in 2016

\begin{tabular}{|c|c|c|c|c|c|c|c|c|c|c|}
\hline \multirow{3}{*}{$\begin{array}{c}\text { Hamlet } \\
\text { name }\end{array}$} & \multicolumn{8}{|c|}{ Behavior } & \multirow{3}{*}{$\mathrm{p}$} & \multirow{3}{*}{ Interpretation } \\
\hline & \multicolumn{2}{|c|}{$0-55$} & \multicolumn{2}{|c|}{$56-79$} & \multicolumn{2}{|c|}{$80-100$} & \multicolumn{2}{|c|}{ Total } & & \\
\hline & $\mathrm{N}$ & $\%$ & $\mathrm{~N}$ & $\%$ & $\mathrm{~N}$ & $\%$ & $\mathrm{~N}$ & $\%$ & & \\
\hline $\begin{array}{l}\text { Surorowo } \\
\text { (focus) }\end{array}$ & 1 & 2 & 11 & 22 & 38 & 76 & 50 & 100 & 0.000 & $\begin{array}{l}\text { Different, } \\
\text { significant }\end{array}$ \\
\hline $\begin{array}{l}\text { Ngaro } \\
\text { (threatened) }\end{array}$ & 5 & 10 & 13 & 26 & 32 & 64 & 50 & 100 & & \\
\hline $\begin{array}{l}\text { Andong } \\
\text { Utara (safe) }\end{array}$ & 26 & 52 & 8 & 36 & 6 & 12 & 50 & 100 & & \\
\hline
\end{tabular}

Table 8. Results of the Kruskal-Wallis Analysis of Differences in Population Density of Rats in Surorowo, Ngaro, and Andong Utara Hamlet, Tutur District, Pasuruan Regency, 2016

\begin{tabular}{|c|c|c|c|c|c|c|c|c|}
\hline \multirow{3}{*}{ Hamlet name } & \multicolumn{6}{|c|}{ Population density of rats } & \multirow{3}{*}{$P$} & \multirow{3}{*}{ Interpretation } \\
\hline & \multicolumn{2}{|c|}{$0-2$} & \multicolumn{2}{|c|}{$2.1-4$} & \multicolumn{2}{|c|}{ Total } & & \\
\hline & $\mathrm{N}$ & $\%$ & $\mathrm{~N}$ & $\%$ & $\mathrm{~N}$ & $\%$ & & \\
\hline $\begin{array}{l}\text { Surorowo } \\
\text { (focus) }\end{array}$ & 50 & 100 & 0 & 0 & 50 & 100 & 0.000 & $\begin{array}{l}\text { Different, } \\
\text { significant }\end{array}$ \\
\hline $\begin{array}{l}\text { Ngaro } \\
\text { (threatened) }\end{array}$ & 48 & 96 & 2 & 4 & 50 & 100 & & \\
\hline $\begin{array}{l}\text { Andong } \\
\text { Utara (safe) }\end{array}$ & 48 & 96 & 2 & 4 & 50 & 100 & & \\
\hline
\end{tabular}

Table 9. Results of Linear Density Regression Analysis of Population Behavior and Environmental Conditions in Tutur District, Pasuruan Regency, 2016

\begin{tabular}{ccccccc}
\hline No & Variable & Anova & Constant & $\begin{array}{c}\text { Variable } \\
\text { coefficient }\end{array}$ & Significance & Interpretation \\
\hline 1 & Environment & 0.000 & 1.848 & -0.019 & 0.000 & $\begin{array}{l}\text { can be used } \\
\text { as a predictor }\end{array}$ \\
\hline
\end{tabular}


Anova analysis results show the value of $p(0,000)$ is less than the value of a (0.050) so that the model can be used. Regression Analysis Results show that environmental conditions can be used as predictors of rat density figures, with the following equation model:

Rat density $=1.848+(-0.019$ Environment $)$

\section{DISCUSSION}

\section{The relationship between population behavior and the environment with the rat density in the plague disease focus area}

Human behavior is the result of all kinds of human experience and interaction with the environment which is manifested in the form of knowledge, attitudes and actions. In accordance with this limitation, health behavior can be formulated as a form of experience and interaction of individuals with their environment, especially those concerning knowledge and attitudes about health. Active behavior can be seen, while passive behavior does not appear, such as knowledge, perception, or motivation. Some experts distinguish forms of behavior into three domains, namely knowledge, attitudes. thi actions or strings we hear by the terms lrstrdedge, attitude, practice (Sarwono 2004).

The human environment basically consists of two parts, internal and external. The internal environment is a dynamic and balanced state called homeostasis, while the external living environment is an environment outside the human body consisting of three components, namely the physical environment, the biological environment and the chemical environment.

\section{Relationship between environmental conditions and rat density}

The relationship between environmental conditions and rat density in focus areas based on the results of the study showed that there was a significant relationship between environmental conditions and rat density. The environmental observations of the Surorowo hamlet by ignoring the $70 \%$ petren area are of good value with a low rat density rate of $2.3 \%$. This is in accordance with the research of Arumsari et al (2012), that the condition of the home environment that is not good or even bad is very supportive and suitable for breeding animals such as rats. The presence of rats will describe the home environment that is not maintained, dirty, dirty, humid, lack of lighting and there are indications of poor environmental hygiene management (Ministry of Health of RI 2002).

\section{The relationship between population behavior and the environment with rat density rates in plague disease threatened areas}

Human behavior is the result of all kinds of human experience and interaction with the environment which is manifested in the form of knowledge, attitudes and actions. Behavioral responses can be passive (without action: think, think, act) or active (take action). In accordance with this limitation, health behavior can be formulated as a form of experience and interaction of individuals with their environment, especially regarding knowledge and attitudes about health. Active behavior can be seen, while passive behavior does not appear, such as knowledge, perception. or motivation. Some experts distinguish forms of behavior into three domains, namely knowledge, attitudes, and actions or often we hear in terms of knowledge, attitude, practice (Sarwono 2004). The human environment basically consists of two parts, internal and external.

\section{Relationship between behavior and rat density number}

Based on the results of research in general, the behavior (knowledge of attitudes and actions) of Ngaro hamlet residents which are categorized as threatened with plague disease is good. The results of the calculation of the rat density in the Ngaro sub-village found $2.5 \%$, including low. The low density of rats in the Ngaro hamlet is due to the status of the hamlet which is an area threatened by routine trapping every 3 months. The community is also well aware of bubonic plague and its relationship with rats so that the public knows how to prevent plague. The low density of rats is not followed by a low flea index whether the IPU or GPA is five> 2 , which means the risk of bubonic plague. Statistical test results which state that there is no relationship between respondent behavior with rat density numbers does not mean that it reduces the possibility of bubonic plague in this village. The results of this study are not in line with Raharjo and Ramadhani's (2012) study which states there is a relationship between community behavior and rat density in Boyolali.

\section{Relationship between environment and rat density numbers}

The relationship between environmental conditions and rat density in the Ngaro hamlet based on the results of the study showed that there was a significant relationship between environmental conditions and rat density in threatened areas. Environmental conditions in the Ngaro hamlet are good with a rat density of 2.5 being low. Adequate lighting conditions and good waste management in Ngaro hamlet have an impact on the low 
density of rats. This is consistent with the research of Arumsari et al (2012), that the condition of the home environment that is not good or even bad is very supportive and suitable for breeding animals such as rats. The presence of rats will describe the home environment that is not maintained, dirty, dirty, humid, lack of lighting and an indication of poor environmental management of the home environment (RI Ministry of Health 2002).

\section{The relationship between population behavior and the environment with rat density in safe plague disease areas}

Human behavior is the result of all kinds of human experience and interaction with the environment which is manifested in forms of knowledge, attitudes and actions. In other words, behavior is the response of an individual's reaction to a stimulus that comes from outside or from within. This response can be passive (without action: think, think, act) or be active (take action). In accordance with this limitation, health behavior can be formulated as a form of experience and interaction of individuals with their environment, especially regarding knowledge and attitudes about health. Active behavior can be seen, while passive behavior does not appear, such as knowledge, perception, or motivation. Some experts distinguish forms of behavior into three domains, namely knowledge, attitudes, and actions or often we hear in terms of knowledge, attitude, practice (Sarwono 2004).

The human environment basically consists of two parts, internal and external. The internal environment is a dynamic and balanced state called homeostasis, while the external environment consumes an environment outside of the human body consisting of three components namely the physical environment, biological environment and chemical environment.

\section{Relationship between environment and rat density numbers}

The human environment basically consists of two parts, internal and external. The internal environment is a dynamic and balanced state called homeostasis, while the external environment is an environment outside of the human body consisting of three components namely the physical environment, biological environment and chemical environment. The results of research in the Andong Utara sub-village show that the environment is not good. The rat density is $7 \%$.

The results of research in Andong Utara sub-village indicate that there is a significant relationship between environmental conditions and rat density. This is consistent with the research of Arumsari et al (2012), that the condition of the home environment that is not good or even bad is very supportive and suitable for breeding animals such as rats. The presence of rats will describe the home environment that is not ablaze, dirty. dirty, damp. lack of lighting and an indication of poor environmental management of the house. Ministry of Health of Rl (2002). Poor environmental conditions in this study mean environmental conditions that support the survival of rats as an intermediary animal for bubonic plague. In the Andong Utara sub-village, most of the respondents' houses were not rat proof, lacking lighting, placing open harvests on a roof called Sangiran, in the residents' yard, many vegetations were favored as rats 'nests and hiding places. All of that supports the survival of rats. Environmental conditions that support the survival of rats in the Andong Utara hamlet are increasingly complementing the conditions to be wary of bubonic plague.

\section{Environmental differences with rat density rates in Surorowo, Ngaro and Andong Utara Hamlets in Tutur Subdistrict, Pasuruan Regency, 2016}

The human environment basically consists of two parts, internal and external. The internal environment is a dynamic and balanced state called homeostasis. While the external environment is an environment outside of the human body consisting of three components, namely the physical environment, biological environment and chemical environment. The results of environmental observations and interviews indicate that the Surorowo hamlet has a good environment about bubonic plague, different from the environment in Andong Utara hamlet which has a less favorable environment about bubonic plague. The results of statistical tests using the Kruskal Wallis test show that there are significant differences in the environment in the villages of Surorowo, Ngaro and Andong Utara. The lack of good environment also affects the prevention of bubonic plague. Based on the results of the study it can be concluded that the environment in the villages of Surorowo, Ngaro and Andong Utara can affect the increase in rat density.

\section{CONCLUSION}

There was no relationship between population behavior (knowledge, attitude and actions) with rat density in the plague disease focus area of Surorowo hamlet, Tutur sub-district, Pasuruan Regency 2016. There was significant relationship between environmental conditions and rat density in the plague disease plague disease hamlet focus area Surorowo, Tutur District, Pasuruan Regency, 2016. Besides, there was no relationship between the behavior (knowledge, attitude 
and actions) of the population with the rat density in the threatened area of Ngaro hamlet, Tutur sub-district, Pasuruan Regency in 2016. There was a relationship between environmental conditions and the rat density in the threatened area of Ngaro hamlet plague disease, Tutur District, Pasuruan Regency, 2016. Population behavior with rat density in the safe area of Andong Utara hamlet, Tutur Subdistrict, Pasuruan Regency in 2016 also showed no relationship. Whereas, there was a relationship between environmental conditions and rat density in the safe area of Andong Utara Hamlet plague disease, Tutur District, Pasuruan Regency in 2016. There were differences in population behavior and the environment between focus, threatened and safe areas of plague disease in Tutur District, Pasuruan Regency, 2016.

\section{REFERENCES}

Arumsari W, Sutiningsih D, Hestiningsih R (2012). Analisis faktor lingkungan abiotik yang mempengaruhi keberadaan leptospirosis pada tikus di
Kelurahan Sambiroto, Tembalang, Semarang. Jurnal Kesehatan Masyarakat 1, 514-524

Ministry of Health, Republic of Indonesia (2002). Dirjen PPM\&PL. Jakarta, Pedoman Pengendalian Tikus, Dirjen PPM\&PL

Ministry of Health of RI (2010). Profil pengendalian penyakit dan penyehatan lingkungan. Jakarta, Direktorat Jenderal Pengendalian Penyakit dan Penyehatan Lingkungan.

Ministry of Health of RI (2012). Pelatihan Teknis Pengendalian Penyakit plague disease, Jakarta Direktorat Jenderal Pengendalian Penyakit dan Penyehatan Lingkungan.

Raharjo J, Ramadhani T (2012). Studi kepadatan tikus dan ektoparasit (fleas) pada daerah fokus dan bekas pes. Prosiding Seminar Nasional Kesehatan. Purwokerto, Public Health, UNSOED

Sarwono S (2004). Sosiologi kesehatan: Beberapa konsep beserta aplikasinya. Yogyakarta, Gadjah Mada University Press.

WHO (2016). WHO report on global surveillance of epidemic-prone infectious diseases. Available at https://www.who.int/csr/resources/publications/surveil lance/plague.pdf 